\title{
Ti-6Al-4V Alaşımının Katı Parçacık Erozyon Davranışının Deneysel ve Sayısal Olarak İncelenmesi
}

\author{
${ }^{1}$ Ali İhsan Budur, ${ }^{* 2}$ Hasan Gedikli \\ ${ }^{1}$ Arsin Meslek Yüksekokulu, Gaz ve Tesisat Teknolojisi Programı, Karadeniz Teknik Üniversitesi, Türkiye \\ ${ }^{* 2}$ Mühendislik Fakültesi, Makina Mühendisliği Bölümü, Karadeniz Teknik Üniversitesi, Türkiye
}

\section{Özet}

Bu çalışmada, havacılık sektöründe yaygın olarak kullanılan Ti-6Al-4V alaşımının katı parçacık çarpması altındaki erozyon davranışı deneysel ve sayısal olarak incelenmiştir. Deneysel çalışmalar iki aşamada yürütülmüştür. Malzemenin erozyon performansları ilk aşamada parçacık çarpma hızı $100 \mathrm{~m} / \mathrm{s}$ için 20, 30, 45, $60,90^{\circ}$ çarpma açılarında belirlenmişken, ikinci aşamada $90^{\circ}$ parçacık çarpma açısında ve $100,127,170,210$, $250 \mathrm{~m} / \mathrm{s}$ parçacık çarpma hızlarında belirlenmiştir. Deneyler sonucunda Ti-6Al-4V alaşımında $20^{\circ}$ parçacık çarpma açısından maksimum erozyon miktarı elde edilmişken, minimum erozyon miktarı $90^{\circ}$ de elde edilmiştir. Hesaplamalı akışkanlar dinamiği yöntemiyle elde edilen sayısal sonuçlar, test sonuçları ile oldukça uyumlu elde edilmiştir.

Anahtar Kelimeler: Katı parçacık erozyonu, Ti-6Al-4V alaşımı, Hesaplamalı akışkanlar dinamiği (HAD)

\begin{abstract}
In this study, solid particle erosion behavior of Ti-6Al-4V alloy, widely used in aerospace industry, been investigated experimentally and numerically. Experimental studies have been carried out in two steps. In the first step, erosion performance of the material was determined at different impact angles of 20, 30, 45, 60, 90 for impact velocity of $100 \mathrm{~m} / \mathrm{s}$ while, in the second step, it was determined at impact velocities of 100, 127, 210 and $250 \mathrm{~m} / \mathrm{s}$ for impact angle of $90^{\circ}$. As a result of the experiments, maximum erosion loss for the titanium alloy was obtained at the angle of $20^{\circ}$ while the minimum erosion loss was obtained at the impact angle of $90^{\circ}$. The numerical results by using CFD (Computational Fluid Dynamics) method were obtained quite similar to the test results.
\end{abstract}

Keywords: Solid particle erosion, Ti-6Al-4V alloy, Computational fluid dynamics (CFD)

*Corresponding author: Hasan GEDİKLİ, Address: Mühendislik Fakültesi, Makina Mühendisliği Bölümü Karadeniz Teknik Üniversitesi, 61080, Trabzon TÜRKIYY. E-mail adresi: hgedikli@ktu.edu.tr, Phone: +904623772995 


\section{Giriş}

Katı parçacık erozyonu çarpan parçacıkların hızı, çarpma açısı, hedef malzeme özelliklerine bağlı bir hasar türü olup bir çok parametreyi bir arada içermektedir [1]. Bu parametrelerden en önemlilerinden biri çarpma açısıdır. Çarpma açısı, aşındırıcı parçacıkların hedef malzeme yüzeyine çarptıkları anda, parçacıklar ile hedef yüzey arasında oluşan açı olarak tanımlanmaktadır [2]. Yapılan çalışmalar, her malzemenin, maksimum erozyona uğradıkları bir kritik çarpma açılarının olduğunu göstermektedir. Finnie, sünek ve gevrek malzemelerde, çarpma açısı değişiminin katı parçacık erozyonuna etkisini incelemek için yaptığı deneyler neticesinde sünek malzemelerde maksimum erozyon miktarının $15-30^{\circ}$ arasında, gevrek malzemelerde ise $90^{\circ}$ de gerçekleştiğini tespit etmiştir [3]. Yerramareddy ve Bahadur [4], Ti-6Al-4V alașımı yüzeyine 120 grit silikon karbür aşındırıcı parçacıkları, $55 \mathrm{~m} / \mathrm{s}$ hız ile çarptırmışlardır. Testler sonucunda, titanyum alaşımında maksimum erozyon miktarının $30^{\circ}$ de olduğunu tespit etmişlerdir. Zhou ve Bahadır[5] Ti-6Al-4V alaşımını $25-800^{\circ} \mathrm{C}$ arasında yedi farklı sıcaklığa hava ortamında ısıtarak ulaştırmış ve bu sıcaklık değerlerinde erozyon testlerini yapmışlardır. Bu testlerde 120 grit silikon karbür parçacıklarını, 55- $110 \mathrm{~m} / \mathrm{s}$ parçacık çarpma hızları aralığındaki değişik parçacık çarpma açılarında $\left(10-90^{\circ}\right)$ hedef malzeme yüzeyine çarptırmışlardır. Yapılan testler sonucunda, Ti-6Al-4V alaşımında maksimum erozyon miktarının $30^{\circ}$ olduğunu ve sıcaklığın artmasıyla birlikte bu açı değerindeki erozyon miktarının düzgün olarak arttığını gözlemlemişlerdir. Bununla birlikte $90^{\circ}$ 'de özellikle $650-800{ }^{\circ} \mathrm{C}$ arasında yapılan testlerde erozyon miktarında aşırı bir artış gözlemlemişlerdir. Ally[6], Al6061, Ti-6Al-4V ve 316 paslanmaz çelik malzemelerinin erozyon davranışlarını birbirleriyle kıyaslamak amacıyla $50 \mu \mathrm{m}$ boyutunda $\mathrm{Al}_{2} \mathrm{O}_{3}$ aşındırıcı parçacıklarını değişik parçacık çarpma açılarında $(30,45,60$ ve 90) çarptırarak yaptığ 1 testler neticesinde en fazla erozyonun 316 paslanmaz çelikte en az aşınmanın da Al6061 alüminyum alaşımında olduğunu tespit etmiştir. Avcu[7], değişik basınç değerlerinde (1.5, 3 ve 4 bar) ve değişik parçacık çarpma açısı $\left(30,60\right.$ ve $\left.90^{\circ}\right)$ değerlerinde Ti-6Al-4V alaşımı üzerinde yaptığ 1 testlerde erozyon davranışı için özgün bir görüntü analiz yöntemi geliştirmiştir.

Katı parçacık erozyonu çalışmalarında, 1990'lı yıllardan itibaren sayısal yöntemlerde kullanılmaya başlanmıştır. Katı parçacık erozyonunun sayısal olarak modellenmesinde birçok çalışma yapılmış ve bu çalışmalarda katı parçacık erozyonuna etki eden parametreler sistematik olarak incelenmiştir. Hesaplamalı akışkanlar dinamiği de katı parçacık erozyonunun sayısal modellemesinde kullanılan önemli bir yöntemdir. Bu yöntem yardımıyla, bir akış ortamında karmaşık geometriye sahip parçalarda oluşan katı parçacık erozyonu hesaplanabilmektedir. Shin[8], ticari ANSYS-Fluent paket programı kullanarak değişik çalışma şartları için bir helikopter palinin yüzeyindeki erozyonu belirlemek için iki ve üç boyutlu sayısal analizler yapmıştır. Araştırmacı analizlerde, k- $\omega$ SST türbülans modeli kullanmış ve analiz sonuçlarının test sonuçlarıyla yüksek derecede uyum içerisinde olduğunu tespit etmiştir.

$\mathrm{Bu}$ çalışma kapsamında, havacılık sektöründe yoğun bir kullanım alanına sahip bir titanyum alaşımı olan Ti-6Al-4V alaşımının katı parçacık erozyonu davranışı erozyon tesleri ve sayısal olarak incelenmiştir. Böylece Ti-6Al-4V malzemesinin literatürde mevcut olmayan yüksek hızlarda ki erozyon performansı belirlenmeye çalışılmıştır. Erozyon testleri iki aşamada gerçekleştirilmiş olup birinci aşamada; Ti-6Al-4V alaşımının katı parçacık erozyonu davranışının parçacık çarpma açısına göre değişimi incelenmiştir. Bunun için sabit bir parçacık çarpma hızında $(100 \mathrm{~m} / \mathrm{s})$ ve değişik çarpma açılarında $\left(20,30,45,60,90^{\circ}\right)$ erozyon testleri yapılmıştır. İkinci 
aşamadaki erozyon testleri ise sabit $90^{\circ}$ çarpma açısında ve değişik parçacık çarpma hızlarında $(100,127,170,210$ ve $250 \mathrm{~m} / \mathrm{s})$ gerçekleştirilmiştir. Böylece bu malzemenin farklı çarpma hızı ve çarpma açılarındaki erozyon performansı belirlenmiştir. Çalışmanın sayısal kısmında erozyon davranışı, hesaplamalı akışkanlar dinamiği (HAD) yardımıyla belirlenmiştir. Bunun için ANSYSFluent ticari paket programı kullanılmıştır.

\section{Gereç ve Yöntem}

\subsection{Erozyon Testleri}

Katı parçacık erozyonu testlerinin yapıldığı test düzeneği Şekil 1 ve Şekil 2'de verilmiştir. Düzenekte katı parçacıkların hızı 50 m/s den 300 m/s hıza kadar ayarlanabilmektedir. Bunun için bir hava-parçacık karışım tankı ve 3.125 mm iç çaplı yakınsak-ıraksak nozul kullanılmıştır. Ayrıca nemlendirici cihazı ile basınçlı havanın nemi alınmaktadır. Bu tankın içerisinde de bir adet hassas dozajlama düzeneği bulunmakta olup, düzenek yardımıyla $0.2 \mathrm{~g} / \mathrm{dk}$ hassasiyet ile sisteme parçacıklar gönderilmektedir.

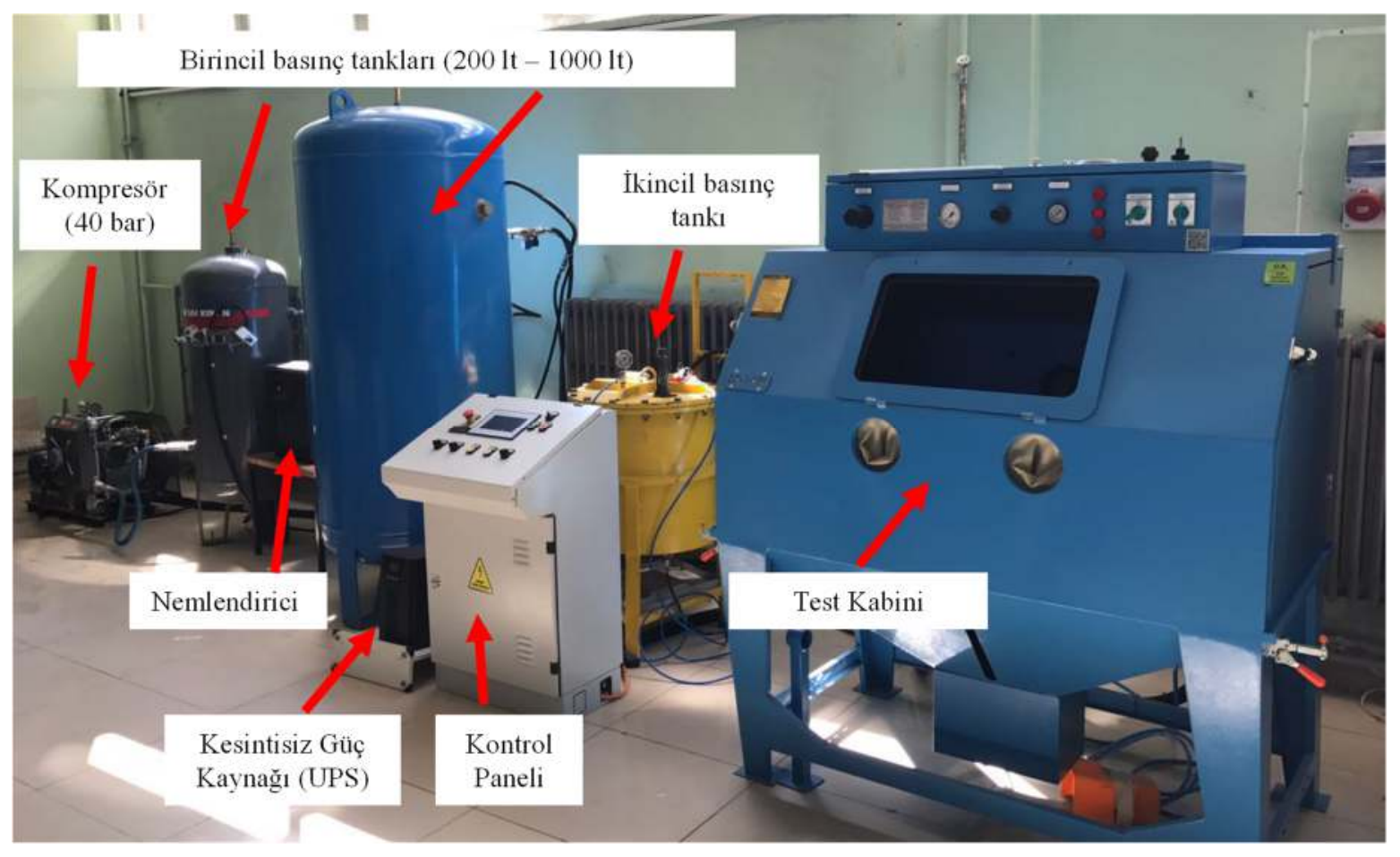

Şekil 1. Katı parçacık erozyon testleri için kullanılan düzeneği

Şekil 2'de detaylı olarak test kabininin iç kısmı gösterilmiştir. Test kabininde çarpma açısı ve nozul mesafesi ayarlanabilmektedir. 


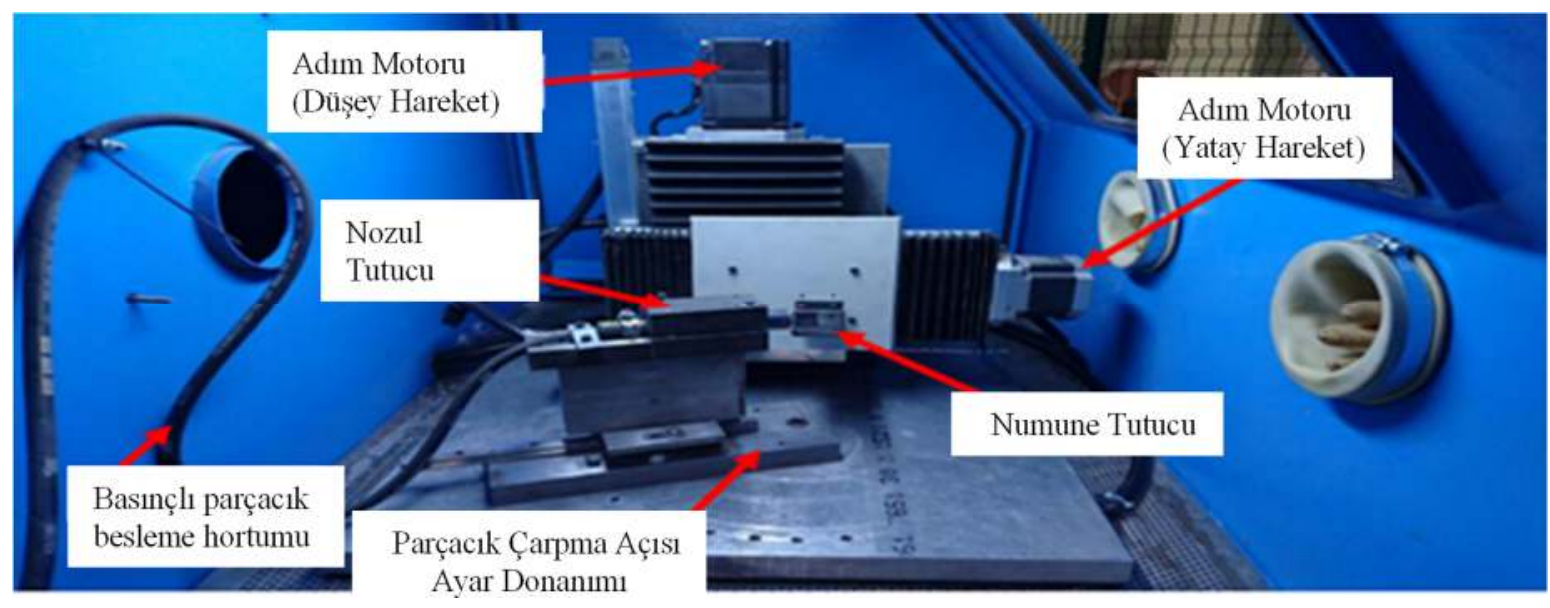

Şekil 2. Test düzeneği kabini içi

Testlerde Ti-6Al-4V alaşımının erozyon davranışı test edilmiştir. Bu alaşım yüksek mukavemet özelliği sahip olup havacılık, denizcilik ve medikal sanayisinde yaygın olarak tercih edilmektedir[9].

\subsection{Hesaplamalı Akışkanlar Dinamiği Yöntemi İle Modelleme}

Hesaplamalı akışkanlar dinamiği, akış ortamında karmaşık geometriye sahip parçalarda erozyon miktarının hesaplanmasında son yıllarda güçlü bir araç olarak kullanılmaktadır. ANSYS-Fluent yazılımı kullanılarak oluşturulan model Şekil 3'de gösterilmiştir.

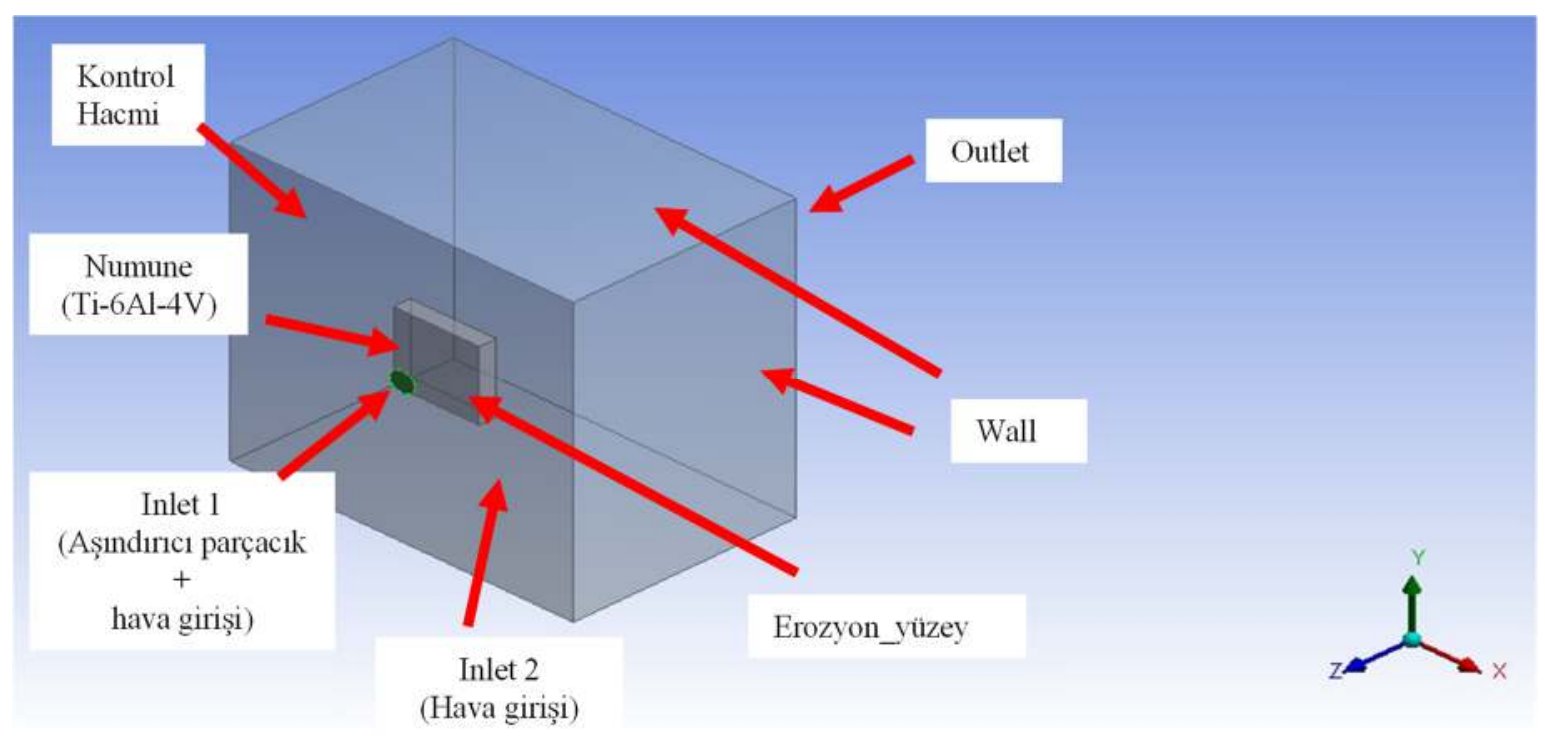

Şekil 3. Ti-6Al-4V alaşım malzemesi için oluşturulan sayısal erozyon modeli

Programda aşındırıcı parçacıkların ortama giriş yaptığı nozul ucu Inlet1, havanın ortama giriş kısmı ise Inlet2 olarak tanımlanmıştır. Havanın ortamdan çıkış yaptığı arka kısım Outlet, kontrol 
hacminin alt, üst ve yan kısımlarının hepsi Wall olarak tanımlanmıştır. Diğer çarpma açılarındaki erozyon testlerinde ise numune $\mathrm{X}$ düzleminde döndürülerek yeni modeller oluşturulmuştur. Modelde akış ortamı ve numune için yaklaşık 500784 adet hexagon elemanlarla ağ yapısı oluşturulmuştur. Bu modelde aşınma kalkanı yüzeylerine yakın yerlerde yoğunlaştırılmış ağ yapısı kullanılmıştır. Model için oluşturulmuş ağ yapısı Şekil 4'de verilmiştir.

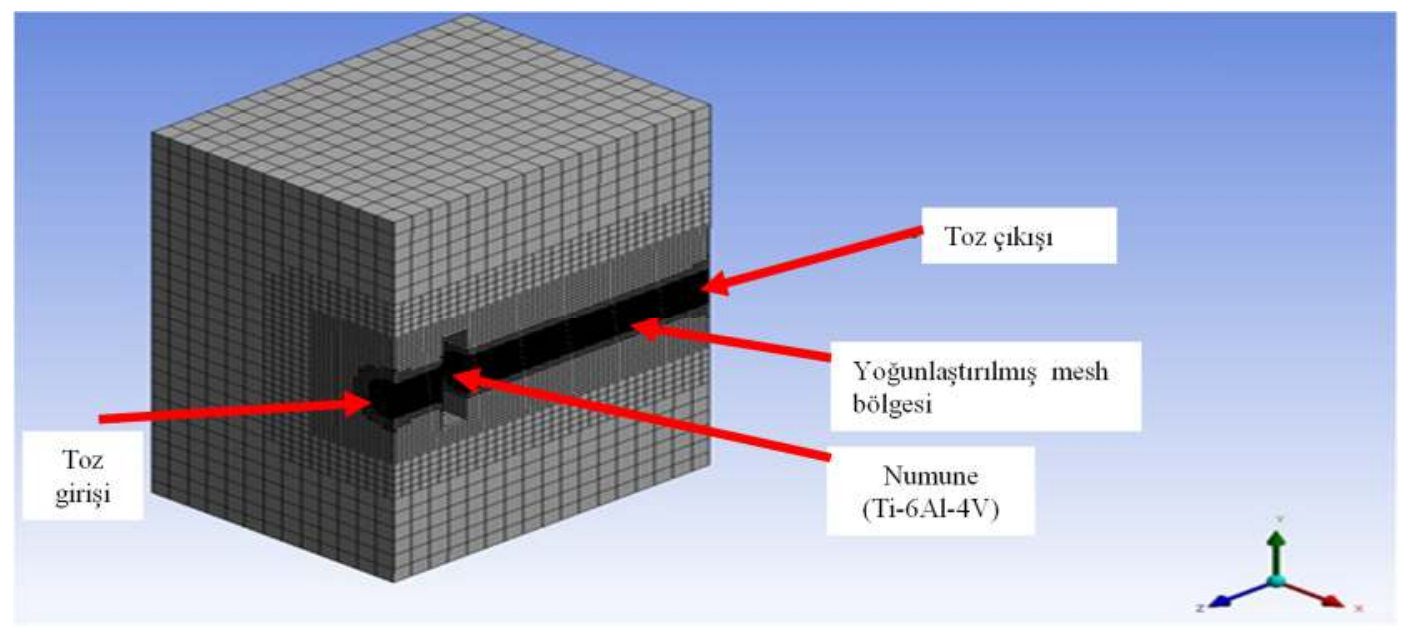

Şekil 4. Ti-6Al-4V alaşım malzemesi için oluşturulan ağ örgüsü

Akışkanlar dinamiği yaklaşımıyla gerçekleştirilen analizlerde en iyi yakınsama veren model k- $\omega$ türbülans modeli seçilmiştir. Erozyon modellemelerinde DNV (2007) firmasına tarafindan geliştirilen ve Denklem 1'de verilen erozyon eşitliği kullanılmıştır [10].

$$
E_{R}=\sum_{i=1}^{N_{i}} \frac{\dot{m}_{i} \times K \times V_{i}^{n} \times F(\alpha)}{A_{i}}
$$

Bu denklemde;

$E_{R}$ : Erozyon hiz yoğunluğu $\left(\mathrm{kg} / \mathrm{m}^{2} \mathrm{~s}\right)$

$\mathrm{m}_{\mathrm{i}}$ : Hedef yüzeye çarpan parçacığın kütlesel debisi $(\mathrm{kg} / \mathrm{s})$

$\mathrm{V}_{\mathrm{i}}$ : Hedef yüzeye çarpan parçacığın hızı $(\mathrm{m} / \mathrm{s})$

$\mathrm{K}$ : Hedef yüzey ve parçacık malzemesine bağlı malzeme sabiti

n : Hedef yüzey ve parçacık malzemesine bağlı hız üssü sabiti

$\mathrm{A}_{\mathrm{i}}$ : Parçacıkların çarptığı hedef yüzeydeki elemanın alanı

$\mathrm{F}(\alpha)$ :Parçacık çarpma açısına bağlı fonksiyon sabiti

olarak tanımlanmakta olup, $\mathrm{K}$ ve $\mathrm{n}$ malzeme sabitleri yapılan erozyon testleri sonucu elde edilmektedir. Ti-6Al-4V malzemesi için K ve n katsayıları sırasıyla $1.72962 \mathrm{E}-8$ ve 2.3 olarak elde edilmiştir [11].

Parçacıkları kontrol hacmine Inlet1' de giriş yapmakta ve Outlet kısmından çıkış yapmaktadır. Inlet kısmına ANSYS-Fluent programında, parçacık girişi için Injection tanımı yapılmıştır. Bu injection tanımlaması yapılırken, ortama giren parçacıkların çapı $50 \mu \mathrm{m}$, hızları ise $100 \mathrm{~m} / \mathrm{s}$ olarak ayarlanmıştır. Ayrıca bu parçacıkların kontrol hacmine giriş debisi de $2.5 \mathrm{gr} / \mathrm{dk}$ olacak şekilde tanımlanmıştır. 


\section{Bulgular}

Ti-6Al-4V alaşımındaki erozyon davranışının parçacık çarpma açısı ve parçacık çarpma hızına göre değişim grafikleri Şekil 5 - 8'de sunulmuştur. Şekil 5'de Ti-6Al-4V alaşımında 100 m/s sabit parçacık çarpma hızındaki değişik parçacık çarpma açılarında oluşan erozyon miktarının zamana göre değişimi verilmiştir. Grafikten görüldügüü üzere en düşük erozyon miktarı $90^{\circ}$ 'lik parçacık çarpma açısında elde edilmiştir. Bu açı değerinde ilk 4. dakika sonunda en düşük erozyon miktarı $3.50 \mathrm{mg}$ olarak belirlenmiştir. Erozyon miktarları 8, 12 ve 16. dakika sonunda ise sırasıyla 6.60, 10.40 ve 13.37 mg olarak elde edilmiştir. Erozyon miktarları, her açı değeri için doğrusal olarak artmiştır.

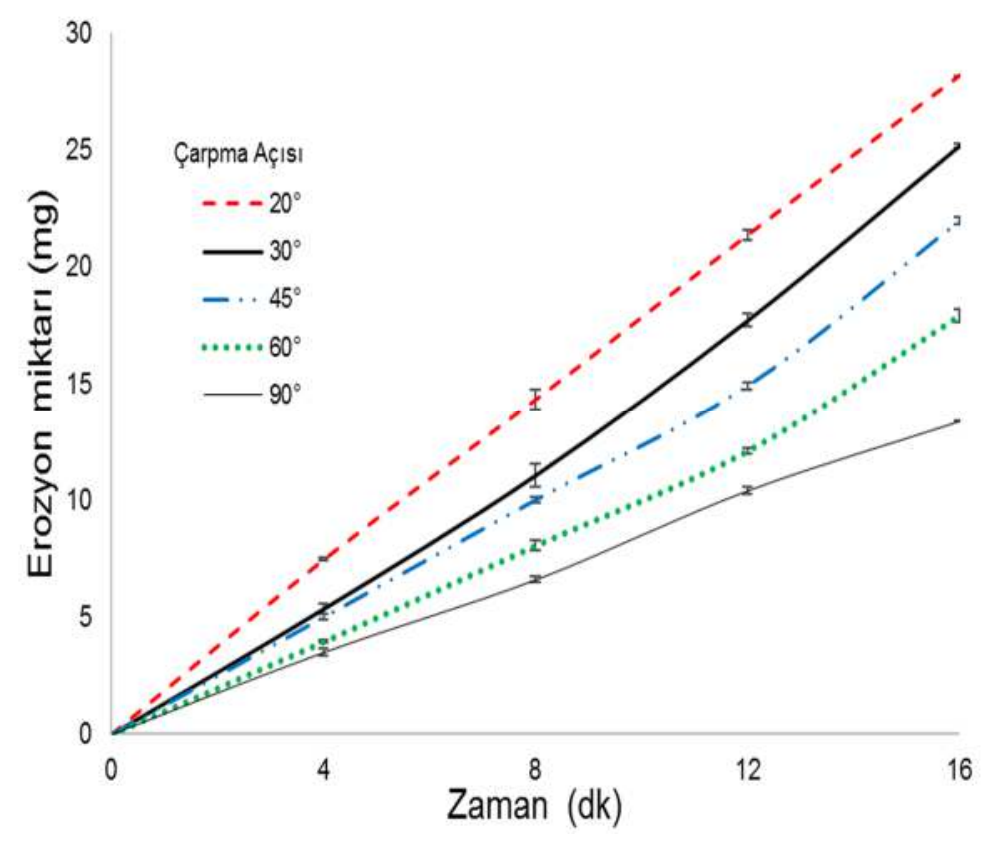

Şekil 5. Ti-6Al-4V alaşım malzemesinde $100 \mathrm{~m} / \mathrm{s}$ parçacık hızı altında değişik parçacık çarpma açılarında yapılan testler sonucu oluşan kütlesel erozyon miktarlarının zamana göre değişimi

Şekil 6'da ise Ti-6Al-4V alaşımında 90 parçacık çarpma açısında elde edilen erozyon değerlerinin parçacık çarpma hızına göre değişimleri verilmiştir. Grafikten görüldüğü gibi en düşük erozyon miktarı $100 \mathrm{~m} / \mathrm{s}$ hız değerinde görülmekte olup, çarpma hızı arttıkça erozyon miktarı artmaktadır. Erozyon miktarları aynı malzeme için; $100 \mathrm{~m} / \mathrm{s}$ çarpma hızında 4, 8, 12 ve 16. dakika sonunda sırasıyla 3.50, 6.60, 10.40 ve $13.70 \mathrm{mg}$ olarak elde edimişken, $127 \mathrm{~m} / \mathrm{s} \mathrm{h} 1 \mathrm{z}$ değerinde sırasıyla 5.80, $12.05,18.00$ ve $24.05 \mathrm{mg}$ olarak elde edilmiştir. $170 \mathrm{~m} / \mathrm{s}$ hızda yapılan testlerde ise 4 . dakika sonunda 11.15 mg erozyon miktarı ölçülmüştür. Bu erozyon miktarı diğer dakikalarda beklendiği gibi zamanlar doğrusal olarak artmıştır. $210 \mathrm{~m} / \mathrm{s}^{\prime}$ lik parçacık çarpma hızındaki testler için ise aynı dakikalar sonunda yapılan ölçümlerde sırasıyla 18.40, 37.35, 56.25 ve $75.40 \mathrm{mg}$ erozyon değerleri elde edilmiştir. Son olarak $250 \mathrm{~m} / \mathrm{s}$ parçacık çapma hızında yapılan testlerde, maksimum erozyon 
miktarları elde edilmiştir. Bu değerlerde 4, 8, 12 ve 16. dakika sonunda sırasıyla 28.15, 56.35, 84.50 ve $112.30 \mathrm{mg}$ olarak belirlenmiştir.

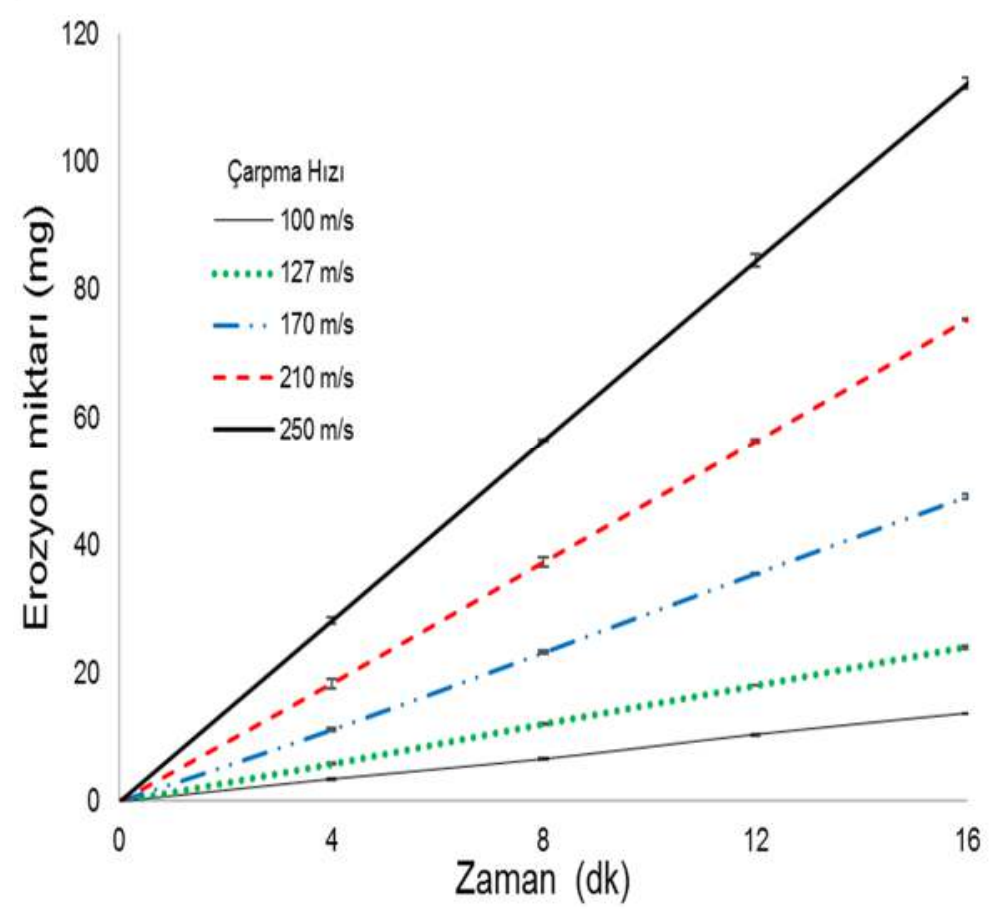

Şekil 6. Ti-6Al-4V alaşım malzemesinde $90^{\circ}$ çarpma açısı altında değişik parçacık çarpma hızlarında yapılan testler sonucu oluşan kütlesel erozyon miktarlarının zamana göre değişimi

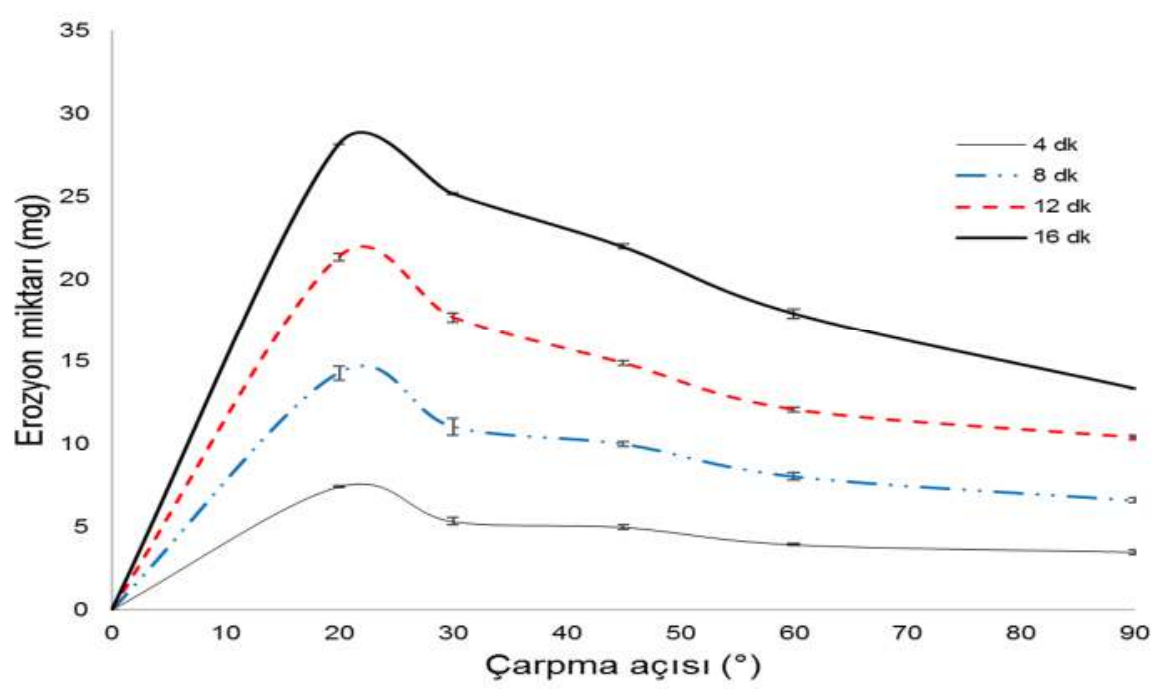

Şekil 7. Ti-6Al-4V alaşım malzemesinde $100 \mathrm{~m} / \mathrm{s}$ parçacık çarpma hızında oluşan kütlesel erozyon miktarlarının parçacık çarpma açısına göre deneysel değişimi

Şekil 7'de Ti-6Al-4V alaşımında oluşan kütlesel erozyon miktarının parçacık çarpma açısına göre değişim grafiği verilmiştir. Grafikte her 4 dakika sonundaki farklı parçacık çarpma açılarında (20, 
30, 45, 60 ve $90^{\circ}$ ) oluşan erozyon miktarları ayrı ayrı gösterilmektedir. Grafikteki 4. dakikadaki erozyon miktarları incelendiğinde; en düşük erozyon miktarı $90^{\circ}$ 'deki çarpma açısında $3.50 \mathrm{mg}$ olarak elde edilmiştir. Erozyon miktarları çarpma açısı $60^{\circ}, 45^{\circ}$ ve $30^{\circ}$ için sırasıyla $3.95 \mathrm{mg}, 5.00$ $\mathrm{mg}$ ve $5.35 \mathrm{mg}$ değerlerine yükselip, çarpma açısı $20^{\circ}$ de ise erozyon miktarı $7.45 \mathrm{mg}$ değerinde maksimum değerine ulaşmıştır.

Şekil 8'de Ti-6Al-4V alaşımında meydana gelen kütlesel erozyon miktarının parçacık çarpma hızına göre değişimi grafiksel olarak verilmiştir. Grafikte her 4 dakika sonunda farklı parçacık çarpma hızlarında $(100,127,170,210,250 \mathrm{~m} / \mathrm{s})$ yapılan testlerde erozyon miktarları ayrı ayrı gösterilmektedir. Grafikteki 4. dakikadaki erozyon miktarları incelendiğinde; en düşük erozyon miktarı $100 \mathrm{~m} / \mathrm{s}$ hız değerinde $3.50 \mathrm{mg}$ olarak ölçülmüş̧tür. Hız değeri arttıkça erozyon miktarı da artmakta olup sirasıyla $127,170,210$ ve $250 \mathrm{~m} / \mathrm{s} \mathrm{h} 1 \mathrm{z}$ değerlerinde, 5.80, 11.15, 18.40 ve $28.15 \mathrm{mg}$ değerine ulaşmıştır. Test süresi arttıkça erozyon miktarı da doğrusal artmaktadır. Bu malzeme için $250 \mathrm{~m} / \mathrm{s}$ çarpma hızında yapılan testlerde 8,12 ve16. dakikalarda ki erozyon miktarları da sırasıyla $56.35,84.50$ ve $112.30 \mathrm{mg}$ olarak ölçülmüştür. Erozyon miktarı her bir zaman değeri için çarpma hızına göre doğrusal olmayan bir şekilde artmıştır.

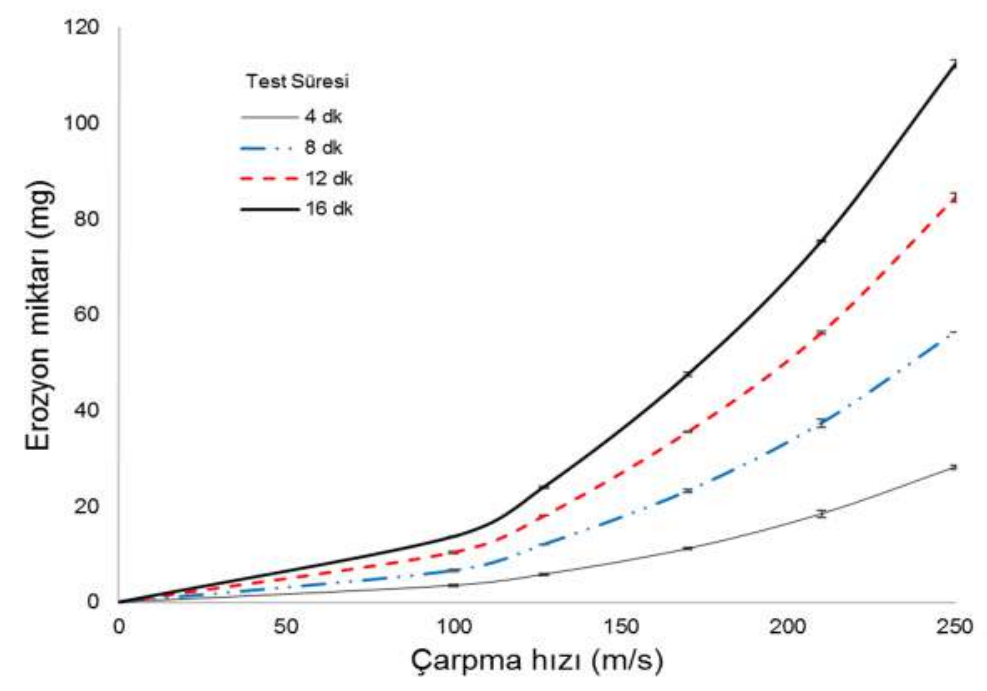

Şekil 8. Ti-6Al-4V alaşım malzemesinde $90^{\circ}$ parçacık çarpma açısında oluşan kütlesel erozyon miktarının parçacık çarpma hızına göre değişimi

Hesaplamalı akışkanlar dinamiği yöntemiyle yapılan modelleme çalışmaları sonucu elde edilen erozyon oranı miktarlarının test sonuçlarıyla karşılaştırılması Şekil 9 ve Şekil10'da verilmiştir. Şekil 9' da sayısal modelleme sonucu elde edilen erozyon miktarlarının parçacık çarpma açısına göre değişiminin test verileriyle karşılaştırılması verilmiştir. Şekilden görüldüğü erozyon oranının çarpma açısına göre değişimi için hesaplamalı akışkanlar dinamiği ile yapılan çalışmalarda elde edilen sonuçlar test sonuçlarıyla çok uyumludur. 




Şekil 9. Ti-6Al-4V titanyum alaşım malzemesi için erozyon miktarının parçacık çarpma açısına göre değişiminin deneysel ve sayısal olarak karşılaştırılması

Şekil 10'da erozyon miktarının parçacık çarpma hızına göre değişimlerinin test ve sayısal sonuçlarının karşılaştırılması verilmiştir. Şekilden görüldüğü gibi test sonucu ile sayısal modelleme sonucunda elde edilen veriler iyi bir şekilde örtüşmektedir.

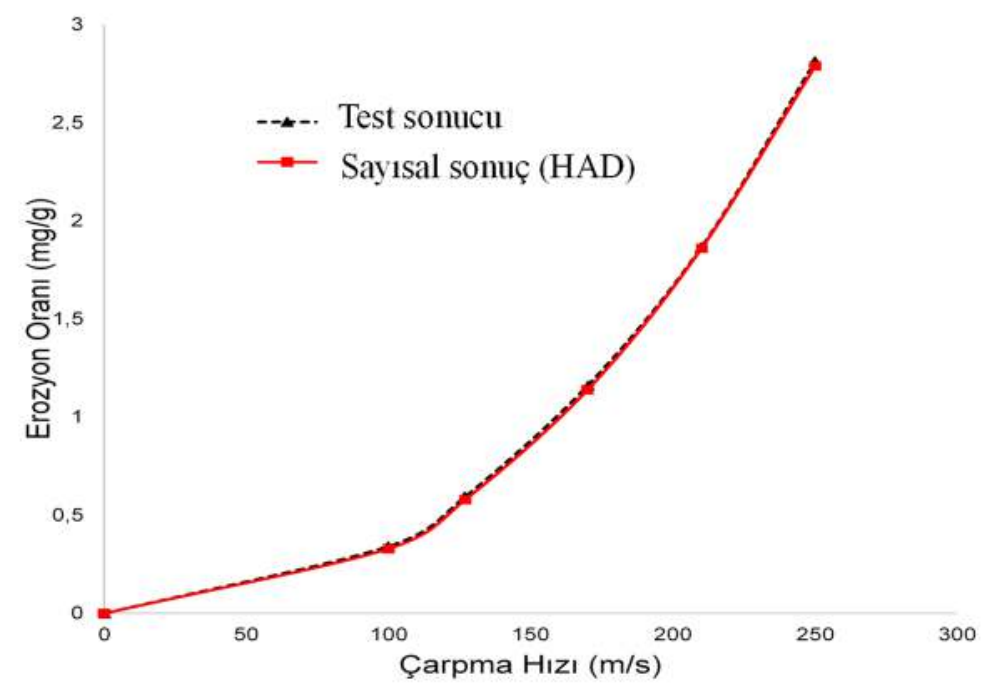

Şekil 10. Ti-6Al-4V alaşım malzemesi için erozyon miktarının parçacık çarpma hızına göre değişim sonuçlarının deneysel ve sayısal olarak karşılaştırılması

\section{Tartışma}

Bu çalışmada kapsamında Ti-6Al-4V alaşımının katı parçacık erozyon davranışının farklı parçacık çarpma açılarında ve parçacık çarpma hızlarında değişimi deneysel ve sayısal olarak incelenmiştir. İnceleme sonucunda aşağıdaki sonuçlara ulaşılmıştır. 
- Ti-6Al-4V alaşımında maksimum erozyon miktarı, $20^{\circ}$ 'deki çarpma açısında oluşmuştur.

- Erozyon miktarı zamana göre doğrusal artmıştır.

- Erozyon miktarı çarpma hızı artışına göre doğrusal olmayan bir şekilde ve önemli derecede artmaktadır.

- Hesaplamalı akışkanlar dinamiği yöntemi kullanılarak katı parçacık erozyon davranışı başarılı bir şekilde modellenebilmektedir.

\section{Kaynaklar}

[1] Finnie, I., Erosion of surfaces by solid particles, Wear, 1960, 3: 87-103.

[2] Nsoesie, S., Experimental Investigation and Analytical Modeling of Solid-Particle Erosion Behavior of Stellite Alloys, Master Thesis, Carleton University, Canada. 2013.

[3] Finnie, I., The Mechanism of Erosion of Ductile Metals, Proc. $3^{\text {rd }}$ U.S. National Congress of Applied Mechanics, 1958, 527-532.

[4] Yerramareddy S., ve Bahadur S., Effect of operational variables, microstructure and mechanical properties on the erosion of Ti-6Al-4V, Wear, 1990, 142, 253-263.

[5] Zhou J., ve Bahadur S., Erosion-corrosion of Ti-6Al-4V in elevated temperature air environment, Wear, 1995, 186, 332-339.

[6] Ally, S., Abrasive Jet Micro-Machining Of Metals, Master Thesis, Ryerson University, Canada, 2010.

[7] Avcu, E., Titanyum Alaşımlarının Partikül Erozyonu İle Pürüzlendirilmesi ve Aşındırılması İşlemlerinin Optimizasyonu, Doktora Tezi, Kocaeli Üniversitesi, Fen Bilimleri Enstitüsü, Kocaeli, 2013.

[8] Shin, B. G., Prediction of Sand Particle Trajectories and Sand Erosion Damage On Helicopter Rotor Blades, Phd Thesis, The Pennsylvania State University, ABD, 2010.

[9] Yıldıran, Y., 3003 H14 Alüminyum Alaşımının Katı Partikül Erozyon Davranışı, Yüksek Lisans Tezi, Kocaeli Üniversitesi, Fen Bilimleri Enstitüsü, Kocaeli, 2013.

[10] DNV, Erosive wear in piping systems, Recommend Practice, 2007, Germany.

[11] Budur, A.İ, Katı Parçacıkların Metalik Yüzeylerde Oluşturduğu Erozyonun Deneysel ve Sayısal Olarak İncelenmesi, Yüksek Lisans Tezi, K.T.Ü., Fen Bilimleri Enstitüsü, Trabzon, 2018. 